LA-14354

Approved for public release;

distribution is unlimited.

Baseline Radionuclide and Nonradionuclide Concentrations in Soils, Vegetation, and Small Mammals at the Proposed Expansion Area at TA-54 Area G 
Edited by Hector Hinjosa, Group IRM-CAS.

Los Alamos National Laboratory, an affirmative action/ equal opportunity employer, is operated by Los Alamos National Security, LLC, for the National Nuclear Security Administration of the U.S. Department of Energy under contract DE-AC52-06NA25396.

This report was prepared as an account of work sponsored by an agency of the U.S. Government. Neither Los Alamos National Security, LLC, the U.S. Government nor any agency thereof, nor any of their employees make any warranty, express or implied, or assume any legal liability or responsibility for the accuracy, completeness, or usefulness of any information, apparatus, product, or process disclosed, or represent that its use would not infringe privately owned rights. Reference herein to any specific commercial product, process, or service by trade name, trademark, manufacturer, or otherwise does not necessarily constitute or imply its endorsement, recommendation, or favoring by Los Alamos National Security, LLC, the U.S. Government, or any agency thereof. The views and opinions of authors expressed herein do not necessarily state or reflect those of Los Alamos National Security, LLC, the U.S. Government, or any agency thereof. Los Alamos National Laboratory strongly supports academic freedom and a researcher's right to publish; as an institution, however, the Laboratory does not endorse the viewpoint of a publication or guarantee its technical correctness. 
LA-14354

Issued: November 2007

Baseline Radionuclide and Nonradionuclide

Concentrations in Soils, Vegetation, and

Small Mammals at the Proposed Expansion

Area at TA-54 Area G

D.D. Romero

P.R. Fresquez 



\title{
BASELINE RADIONUCLIDE AND NONRADIONUCLIDE CONCENTRATIONS IN SOILS, VEGETATION, AND SMALL MAMMALS AT THE PROPOSED EXPANSION AREA AT TA-54 AREA G
}

by

\section{D.D. Romero and P.R. Fresquez}

\begin{abstract}
Area $G$ is a 25.5 -hectare (63-acre), fenced, low-level radioactive solid waste processing and disposal area located on the east end of Mesa del Buey at Technical Area 54 at Los Alamos National Laboratory. This disposal area has been in existence since 1957 and is expected to be filled by the year 2015. Thus, a new area, located adjacent to Area G on the west side, has been proposed for the expansion of disposal activities. Since 1994 to the present, baseline levels of several radionuclides and nonradionuclides have been collected in soils, vegetation, and small mammals (field mice and rock squirrels). These data will be used to assess potential impacts, if any, at the expanded site once operations begin. Baseline statistical reference levels (BSRLs) (mean plus three standard deviations $=99 \%$ confidence level) of radionuclides and nonradionuclides in these media were calculated and compared with regional statistical reference levels (RSRLs). RSRLs are calculated from regional areas away from the influence of the Laboratory and represent natural and worldwide fallout sources. BSRLs in most media, with the exception of field mice (mostly Peromyscus spp.), compare very well with RSRLs. Field mice, probably because they are mobile and may have spent time within the active disposal area, appeared to be impacted by Area $G$ operations as they contained higher concentrations of ${ }^{3} \mathrm{H},{ }^{238} \mathrm{Pu},{ }^{239,240} \mathrm{Pu}$, and ${ }^{241} \mathrm{Am}$ as compared to RSRLs. Overall, however, the preoperational data from the other media show that the proposed expansion area has been impacted very little by Area $\mathbf{G}$ operations.
\end{abstract}

\section{Introduction}

Solid radioactive wastes have been disposed of by burial at Los Alamos National Laboratory since the early 1940s (Purtymun et al., 1980). Area G is a 25.5-hectare (63acre) low-level radioactive waste processing area located on the east end of Mesa del 
Buey at Technical Area (TA) 54 (Figure 1). Area G was established in 1957 and is the Laboratory's primary radioactive solid waste burial and storage site (Soholt, 1990). Wastes include contaminated equipment, paper, clothing, building materials, soils, and process wastes and are placed in pits, trenches, or shafts and then covered with fill material (Hansen et al., 1980). Tritium, ${ }^{238} \mathrm{Pu},{ }^{239,240} \mathrm{Pu},{ }^{241} \mathrm{Am},{ }^{234} \mathrm{U},{ }^{235} \mathrm{U},{ }^{238} \mathrm{U}$, and a variety of fission and activation products are the main radionuclides in waste materials deposited at Area G (U.S. DOE, 1979).

The Site-Wide Environmental Impact Statement Record of Decision (SWEIS ROD) assessed an expanded alternative that estimated the capacity of future low-level waste disposal at Area $G$ to be greater than the existing capacity. Area $G$ is expected to be filled by 2015. Thus, the SWEIS ROD evaluated a need for an expansion of Area G, and a 10-acre site directly west of Area G was identified as the location for the development of waste management disposal operations for the future (Figure 2) (LANL, 2006).

As part of the environmental surveillance program at Area G (Lopez, 2002), soil, vegetation (overstory and understory), and small mammals (field mice and rock squirrels) at the proposed expansion area have been collected since 1994 and analyzed for a host of chemical constituents. These (preoperational) data are meant to represent baseline conditions before any operations are initiated so that future comparisons and potential impacts, if any, can be made. This report summarizes the baseline statistical reference levels (BSRLs), mean plus three standard deviations $=99 \%$ confidence level, of a host of radionuclides and nonradionuclides in these media collected from the proposed expansion area at TA-54 Area G from 1994 through 2005. 


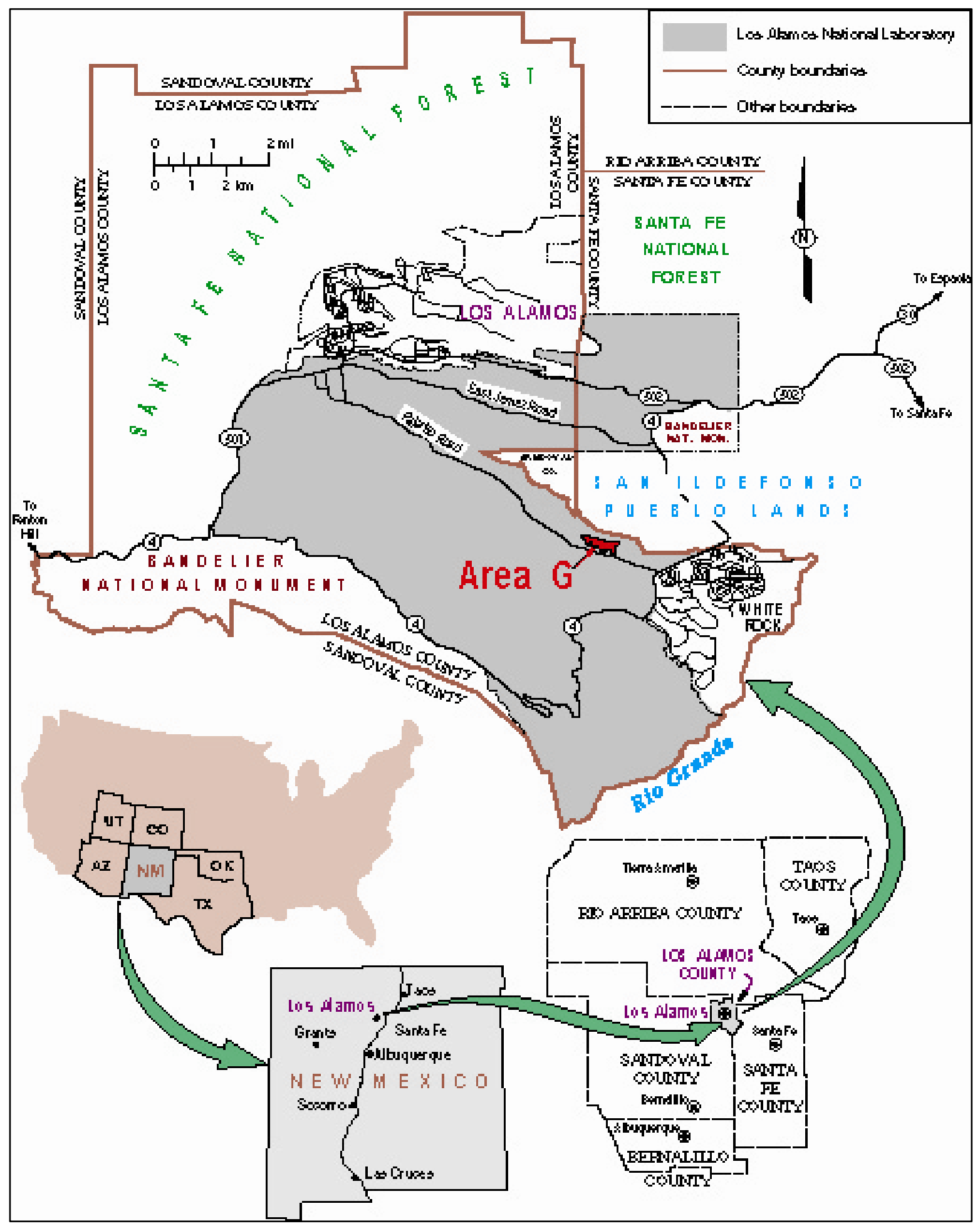

Figure 1. The location of Area G at Los Alamos National Laboratory. 


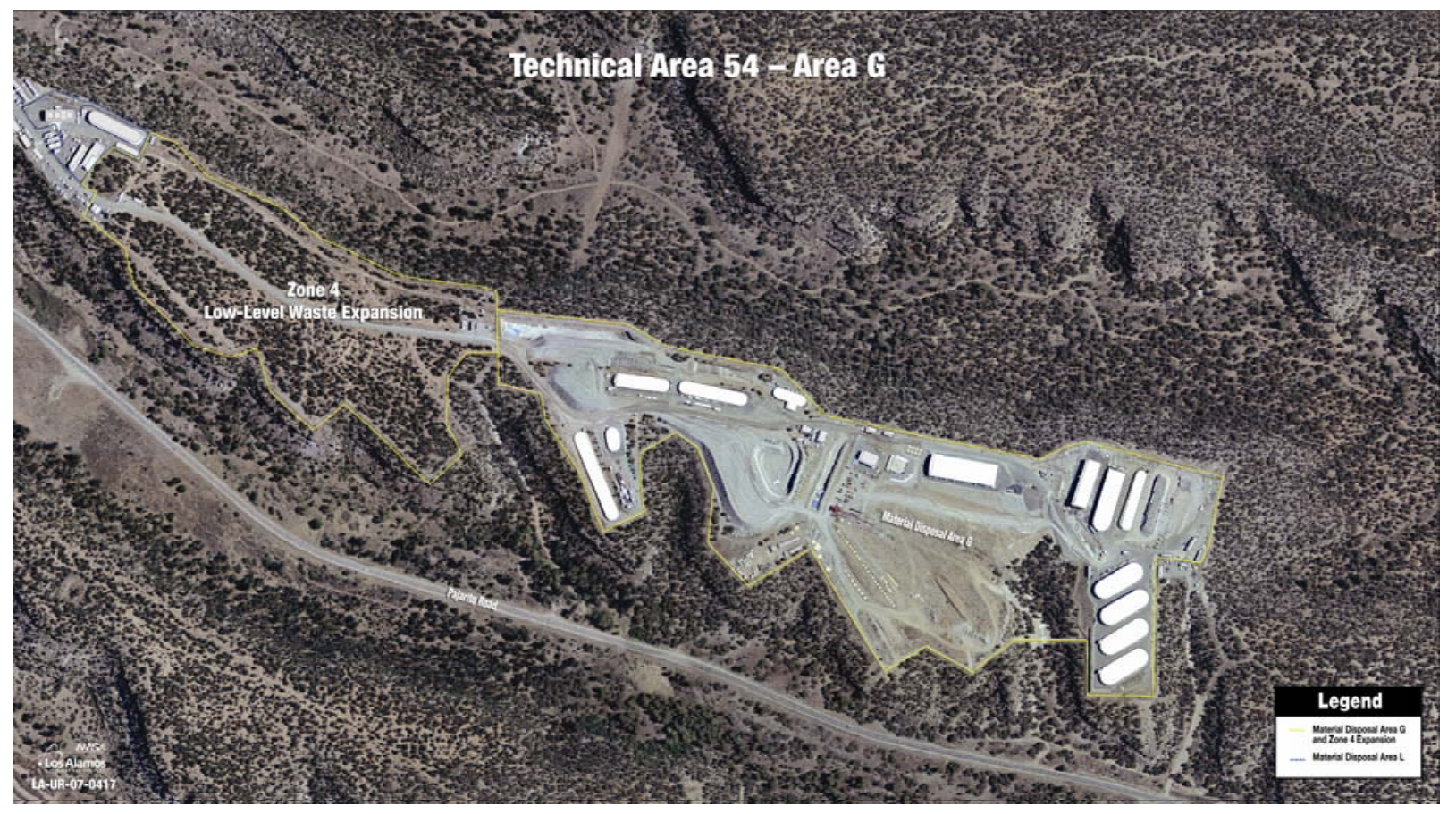

Figure 2. The location of the proposed expansion area relative to Area G.

\section{Methods \\ a. Soil Sampling}

In 1994 and 1995, soil sampling for radionuclides as well as inorganic trace elements was conducted at 27 and 30 locations, respectively, within the expansion area (Conrad et al., 1995; Childs and Conrad, 1999) (Appendixes A and B). From 1996 to 2005, one composite soil sample was collected each year at various locations within the expansion area (Fresquez et al., 1997; 1998; 1999; 2004; 2005a; Nyhan et al., 2000; 2001; 2002; 2004; Fresquez and Lopez, 2004). Soil was collected by using a 4-in.diameter stainless steel ring pushed 2 in. into the soil; five sub-samples were collected at the corners and middle of a 33- by 33-ft square. Samples were mixed and poured into a 500-mL poly bottle. Bottles were marked for identification and sealed with chain-ofcustody tape. All samples were submitted to the Analytic Chemistry group for the years 
1996 through 2000 and to Paragon Analytics from 2001 through 2005 for the analysis of radionuclides $\left({ }^{3} \mathrm{H},{ }^{238} \mathrm{Pu},{ }^{239},{ }^{240} \mathrm{Pu},{ }^{241} \mathrm{Am},{ }^{234} \mathrm{U},{ }^{235} \mathrm{U},{ }^{238} \mathrm{U},{ }^{137} \mathrm{Cs},{ }^{90} \mathrm{Sr},{ }^{228} \mathrm{Ac},{ }^{7} \mathrm{Be},{ }^{214} \mathrm{Bi}\right.$, $\left.{ }^{57} \mathrm{Co},{ }^{60} \mathrm{Co},{ }^{40} \mathrm{~K},{ }^{54} \mathrm{Mn},{ }^{22} \mathrm{Na},{ }^{212} \mathrm{~Pb},{ }^{214} \mathrm{~Pb},{ }^{208} \mathrm{Tl}\right)$ and several nonradionuclides (Ba, Be, $\mathrm{Cr}$, $\mathrm{Ni}, \mathrm{Sb}, \mathrm{As}, \mathrm{Cd}, \mathrm{Pb}, \mathrm{Se}, \mathrm{Ag}, \mathrm{Hg}$, and $\mathrm{Tl}$ ). Tritium was reported in $\mathrm{pCi} / \mathrm{mL}$, other radionuclides were reported in $\mathrm{pCi} / \mathrm{g}$ dry, and metals were reported in $\mathrm{mg} / \mathrm{kg}$ dry (ppm).

\section{b. Plant Sampling}

From 1996 to 2005, samples of overstory vegetation, mostly juniper trees, and understory vegetation, mostly grasses and forbs, were collected from the same 33- by 33$\mathrm{ft}$ plot as the soil sampling in the expansion area (Fresquez et al. 1997; 1998; 1999; 2004; 2005a; Nyhan et al., 2000; 2002; 2004; Fresquez and Lopez, 2004). Samples of the overstory plants consisted of the tips of tree shoots approximately 2 to 6 in. in length, which were collected at a height of 4 to $5 \mathrm{ft}$. Samples of the understory plants consisted of clippings of the top growth cut at the soil level. About 2 to $3 \mathrm{lb}$ of composite material was collected using clean shears. Results are reported in $\mathrm{pCi} / \mathrm{mL}$ for ${ }^{3} \mathrm{H}, \mathrm{pCi} / \mathrm{g}$ ash for radionuclides, and in $\mathrm{mg} / \mathrm{kg}$ dry for the metals.

\section{c. Small Mammal Sampling}

Small mammals consisted of field mice (mostly Peromyscus spp.) and rock squirrels (Sciurus spp.). Sampling of mice at the expansion area was accomplished in 1996 (Biggs et al., 1997), 1997 (Bennett et al., 1998), 1998 (Bennett et al., 2002), and 2002-2003 (Fresquez et al., 2005b). Rock squirrel sampling was done in 2002 (Fresquez et al., 2005b). The trapping location was co-located with the soil and vegetation sampling sites. Each sample consists of about 5 to 10 mice or one rock squirrel. Detailed 
descriptions of trapping methods and analysis methods are available in Biggs et al. (1995) and Bennett et al. (1996).

For the years 1996 through 1998, whole body concentrations were calculated from separate carcass and pelts data. In order to obtain a whole body concentration, conversion of the data was needed (see Appendix C). Whole body mice were analyzed in 2002 and 2003. The BSRLs for mice are reported in $\mathrm{pCi} / \mathrm{g}$ ash for radionuclides, except for ${ }^{3} \mathrm{H}$, which is reported in $\mathrm{pCi} / \mathrm{mL}$.

\section{d. Comparison Levels}

For this summary report, the BSRLs are compared with regional statistical reference levels (RSRLs) to validate the baseline by showing if the expansion area has in any way been impacted from Area G operations. RSRLs are the upper-level background concentration (mean plus three standard deviations $=99 \%$ confidence level) for radionuclides and nonradionuclides in soil, vegetation, and small mammals collected from regional locations away from the influence of the Laboratory over at least the last five sampling periods. RSRLs are calculated as data become available and can be found in the annual issues of the Laboratory's Environmental Surveillance Report.

\section{Results}

a. Radionuclide/Total Trace Element BSRLs in Soils

The results for radionuclide concentrations in soils collected from the proposed expansion area are given in Table 1. Most of the individual results, with the exception of a few actinides, were below RSRLs. Overall, however, the BSRLs were similar to RSRLs. 


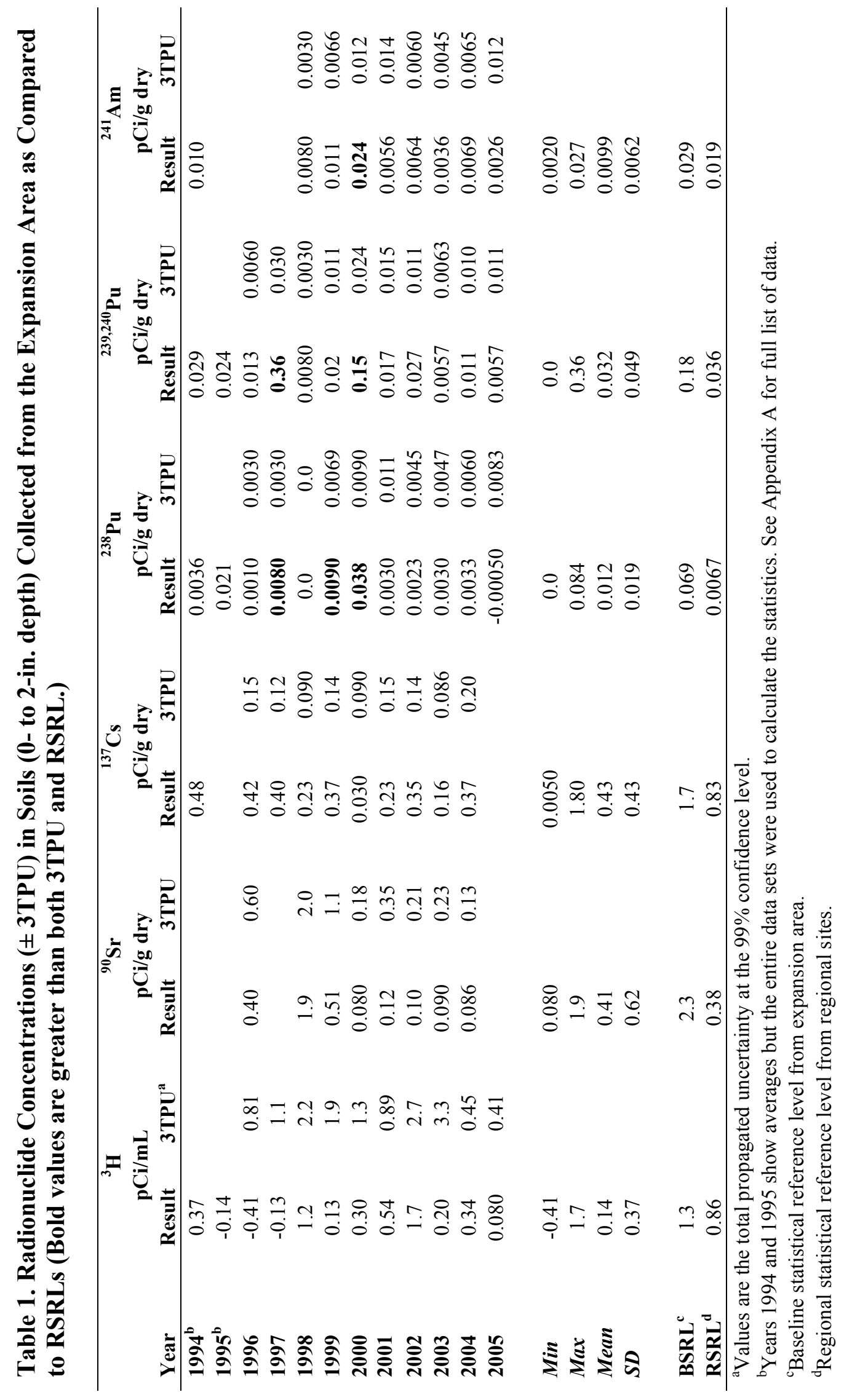




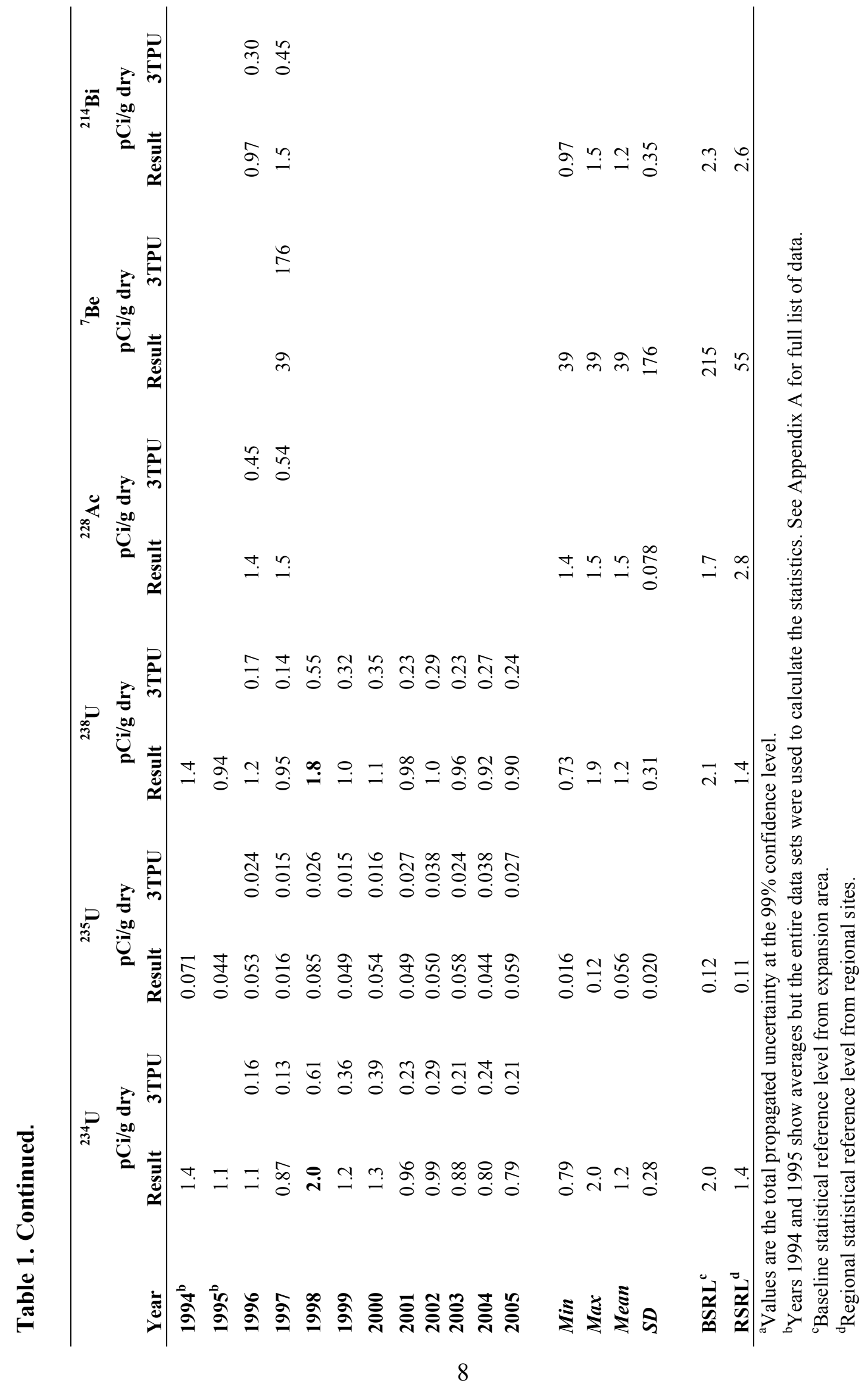




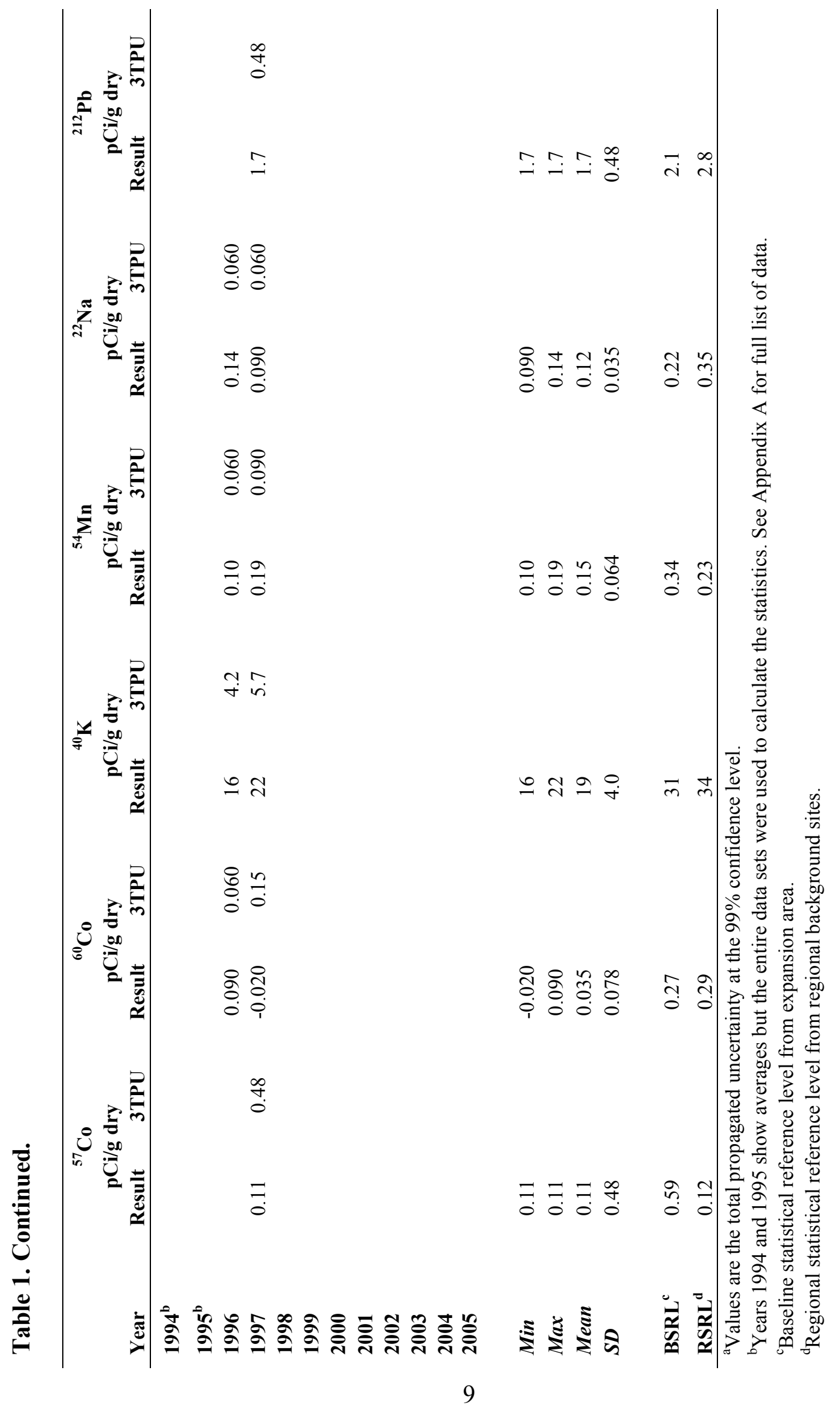




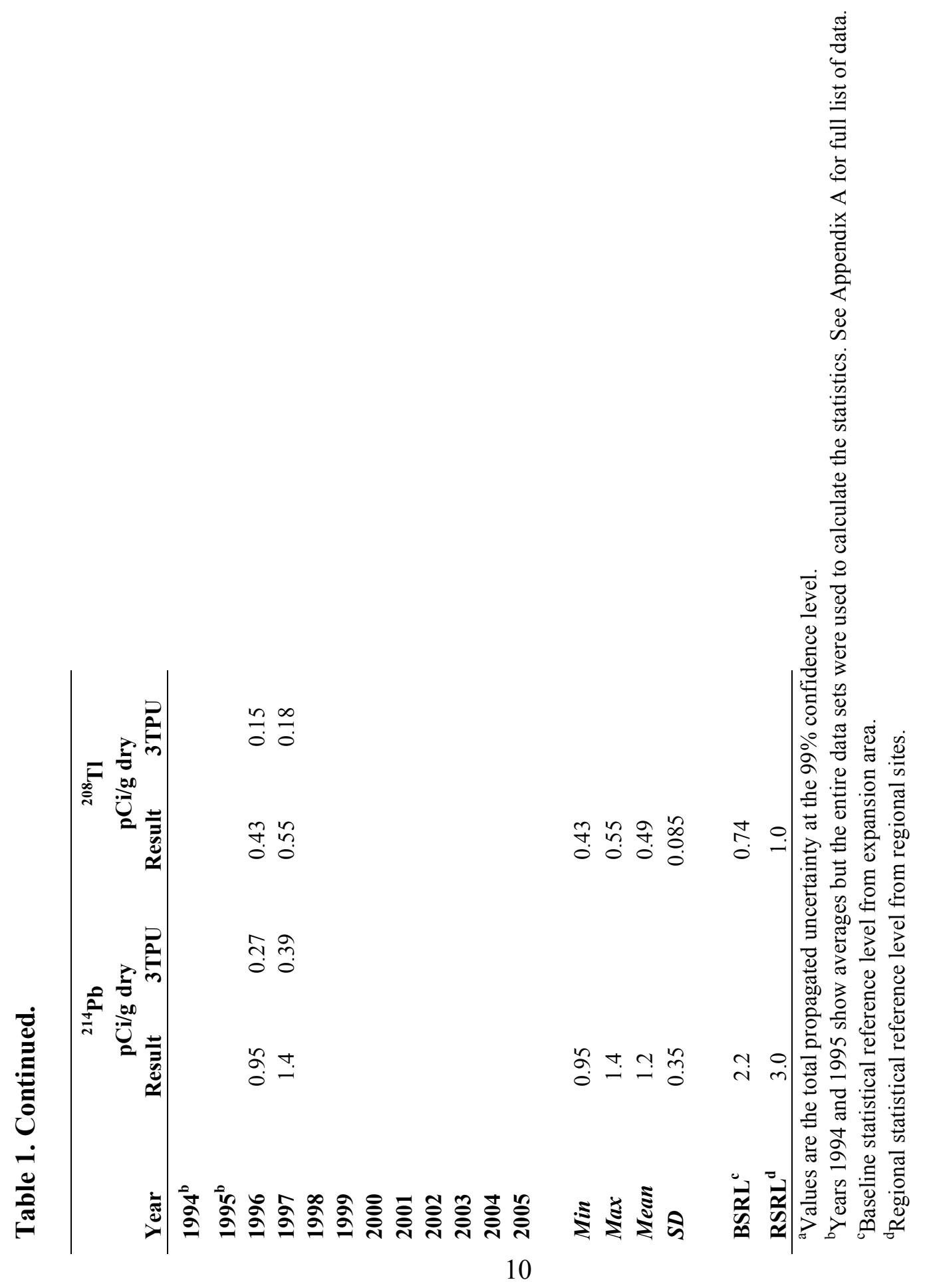


A total of 12 trace element BSRL concentrations for the expansion area were calculated (Table 2). Overall, most of the BSRLs, with the exception of Ag and Se, were similar to the RSRLs. Because the detection levels for many of these elements were high in the early years, the BSRLs for $\mathrm{Ag}, \mathrm{Cd}, \mathrm{Hg}, \mathrm{Ni}, \mathrm{Sb}, \mathrm{Se}$, and $\mathrm{Tl}$ may be biased high. In these cases, the use of RSRLs to evaluate potential impacts may be more appropriate.

\section{b. Radionuclide/Total Trace Element BSRLs in Plants}

The results for radionuclide and metal concentrations in overstory and understory vegetation are given in Tables 3 through 6. Most of all of the individual radionuclide and nonradionuclide results in both overstory and understory vegetation were below the RSRLs. The one exception was ${ }^{3} \mathrm{H}$ in both plant types; detectable ${ }^{3} \mathrm{H}$ in overstory vegetation was higher than the RSRL in two out of nine samples and higher in one out of eight samples in understory vegetation. (Note: A detectable result is one that is higher than three times the analytical uncertainty.) Although the amount of ${ }^{3} \mathrm{H}$ in plants within the expansion area was not extensive, there is a fair amount of ${ }^{3} \mathrm{H}$ uptake by plants within and around the perimeter of Area G (Fresquez et al., 2003). All of the other BSRLs in plants were similar to the RSRLs.

\section{c. Radionuclide Concentrations in Small Mammals}

Field mice samples from the expansion area contained higher amounts of ${ }^{3} \mathrm{H}$, ${ }^{238} \mathrm{Pu},{ }^{239,240} \mathrm{Pu},{ }^{241} \mathrm{Am},{ }^{234} \mathrm{U}$, and ${ }^{238} \mathrm{U}$ than the RSRLs (Table 7). These results, with the exception of uranium isotopes, reflect those usually reported in soil and vegetation (Fresquez, 2007) and mice (Fresquez et al., 2005b) samples collected within the active waste management area. The uranium in mice from the expansion area is naturally occurring (e.g., the ratio of ${ }^{234} \mathrm{U}$ and ${ }^{238} \mathrm{U}$ is close to one) and is not a concern; the 


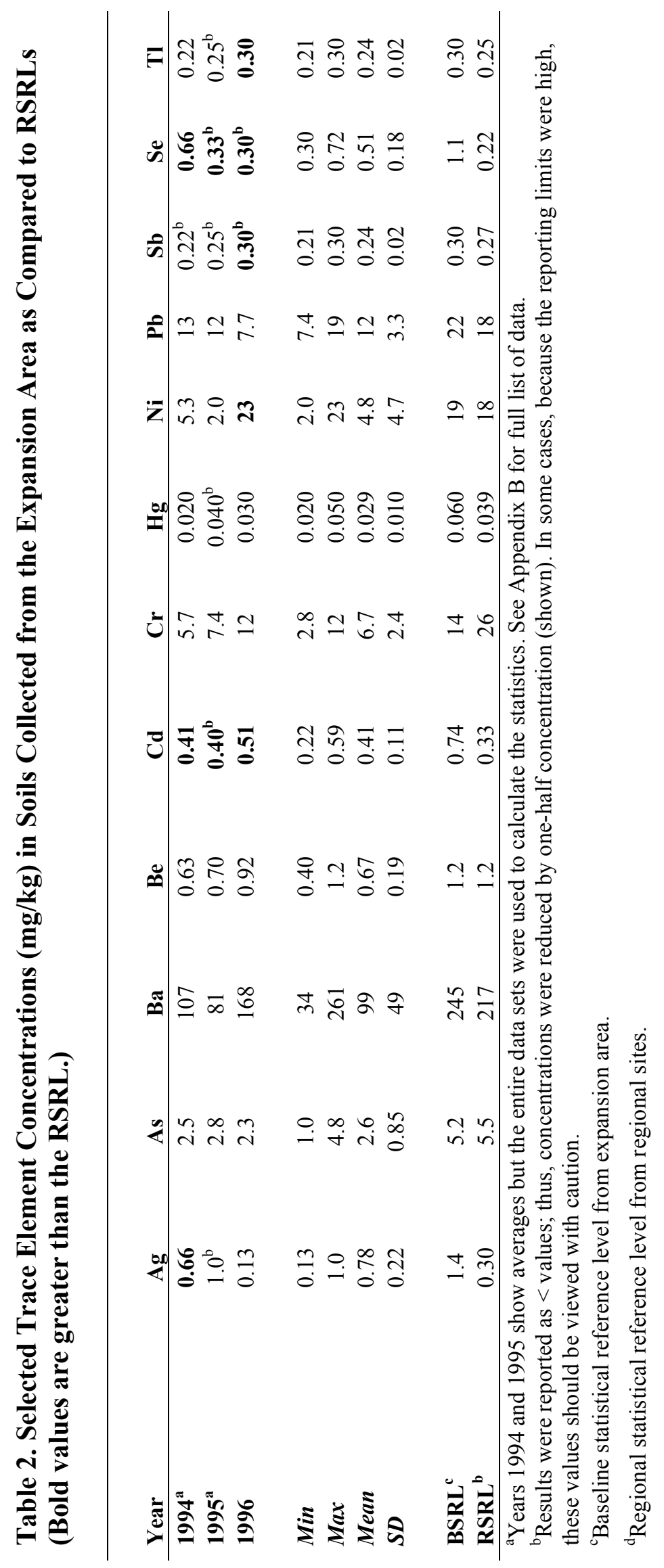




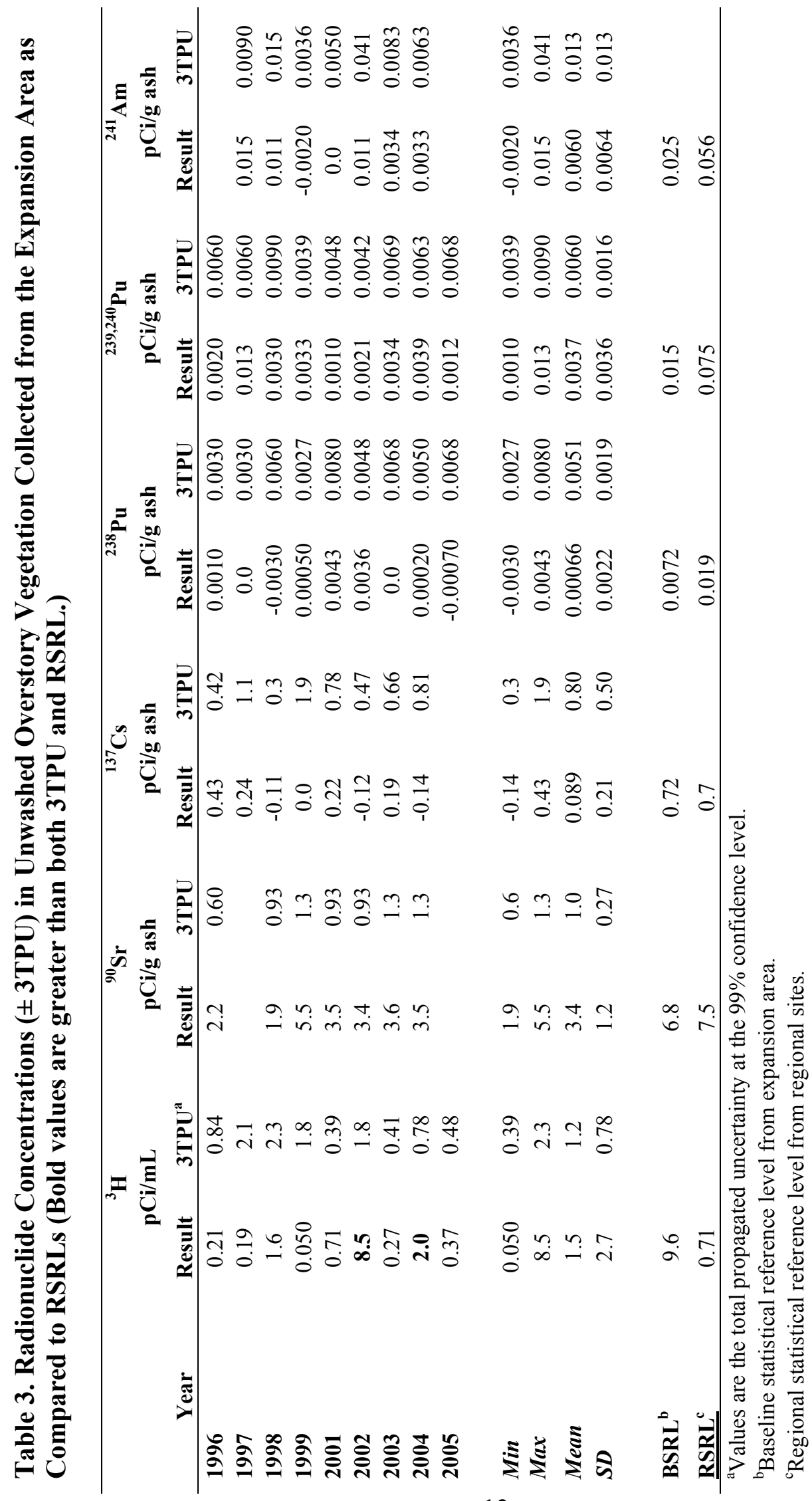




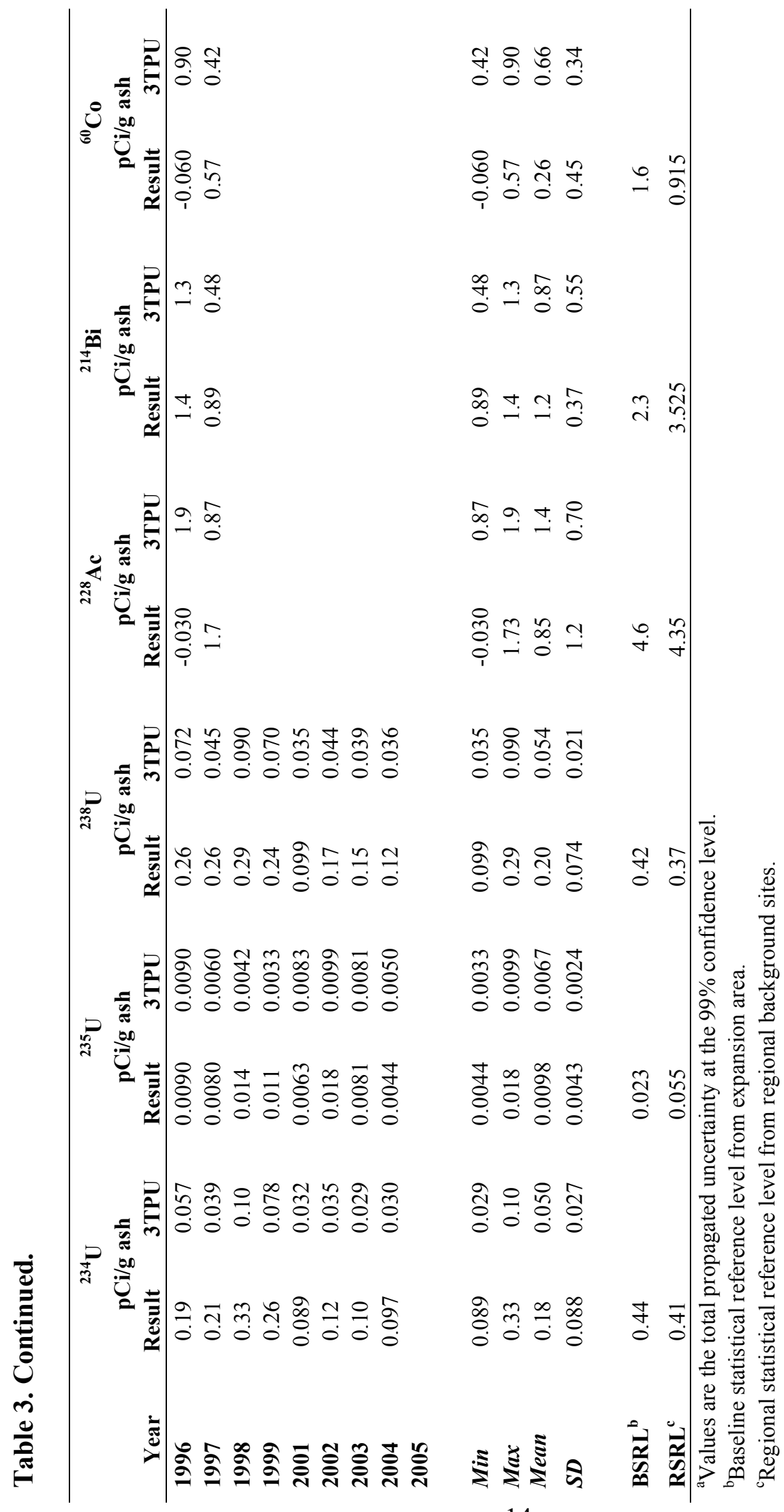




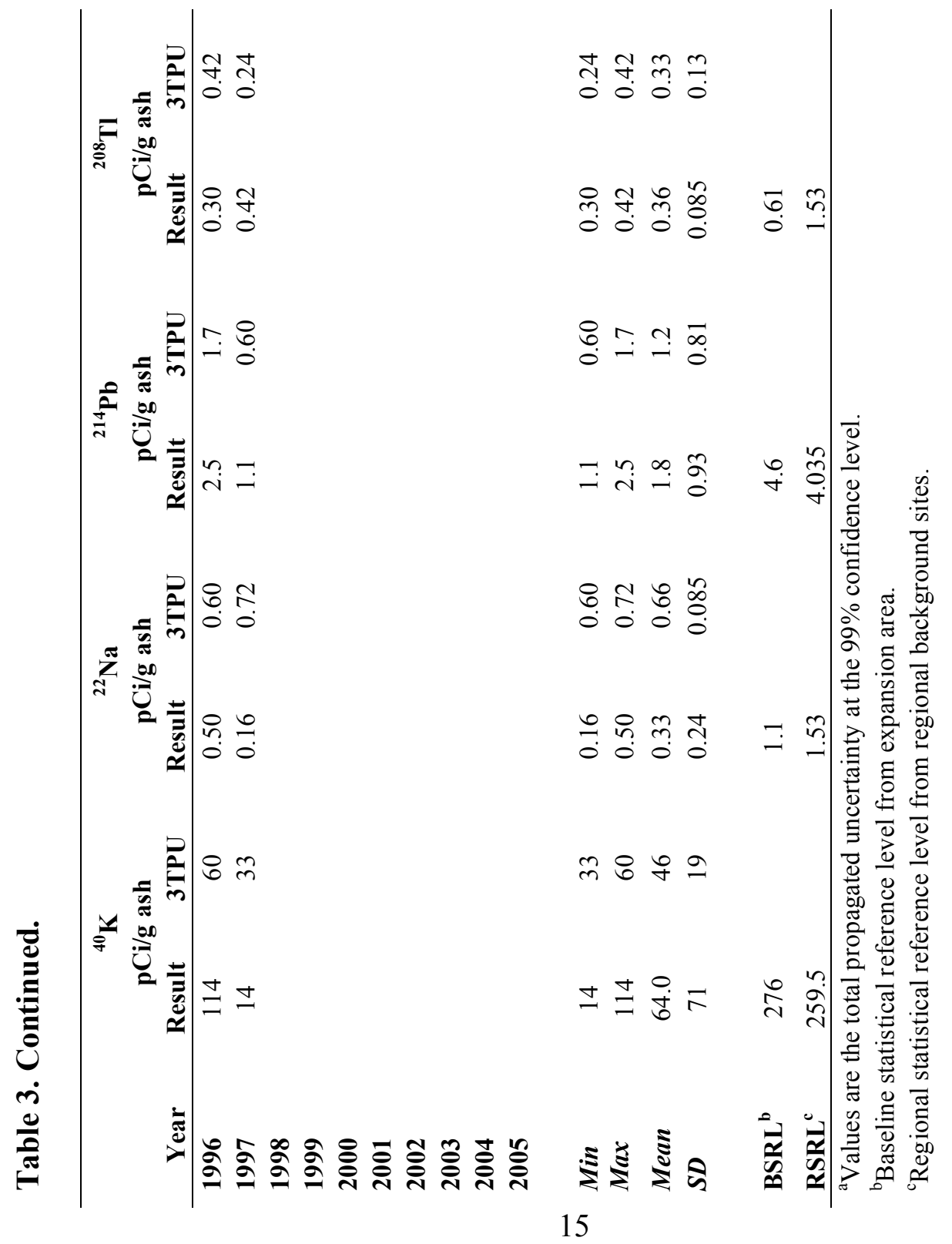




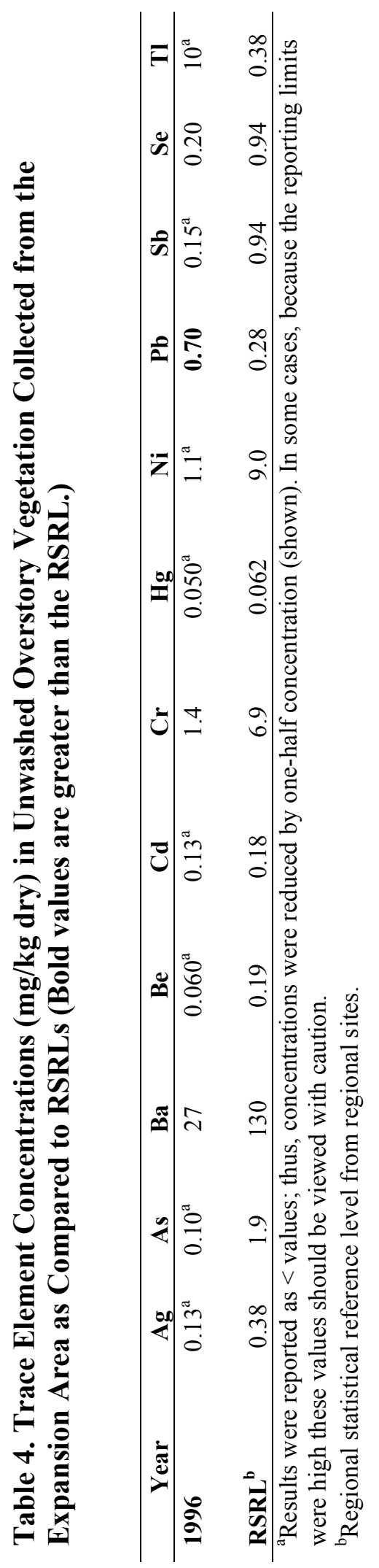




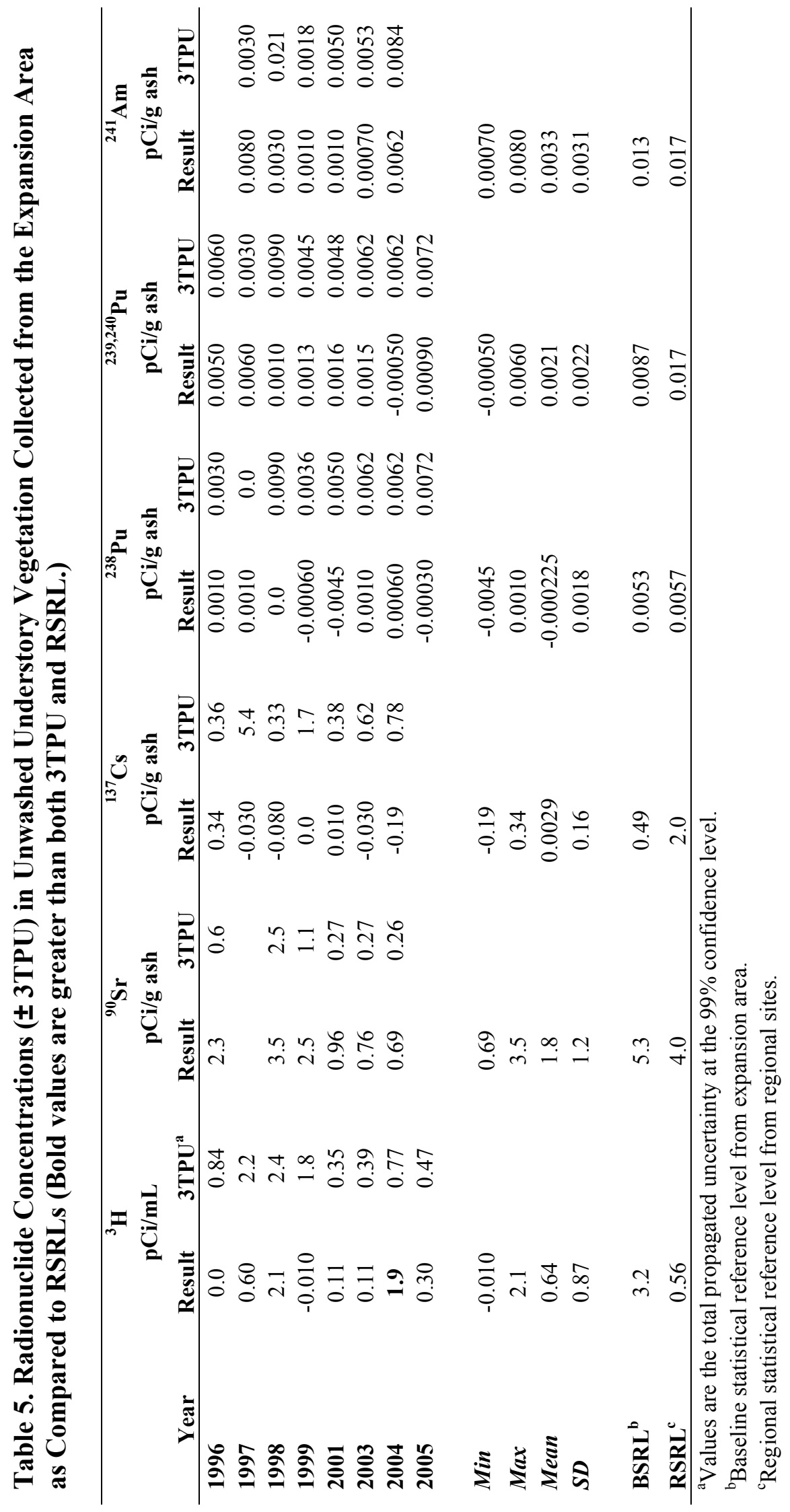




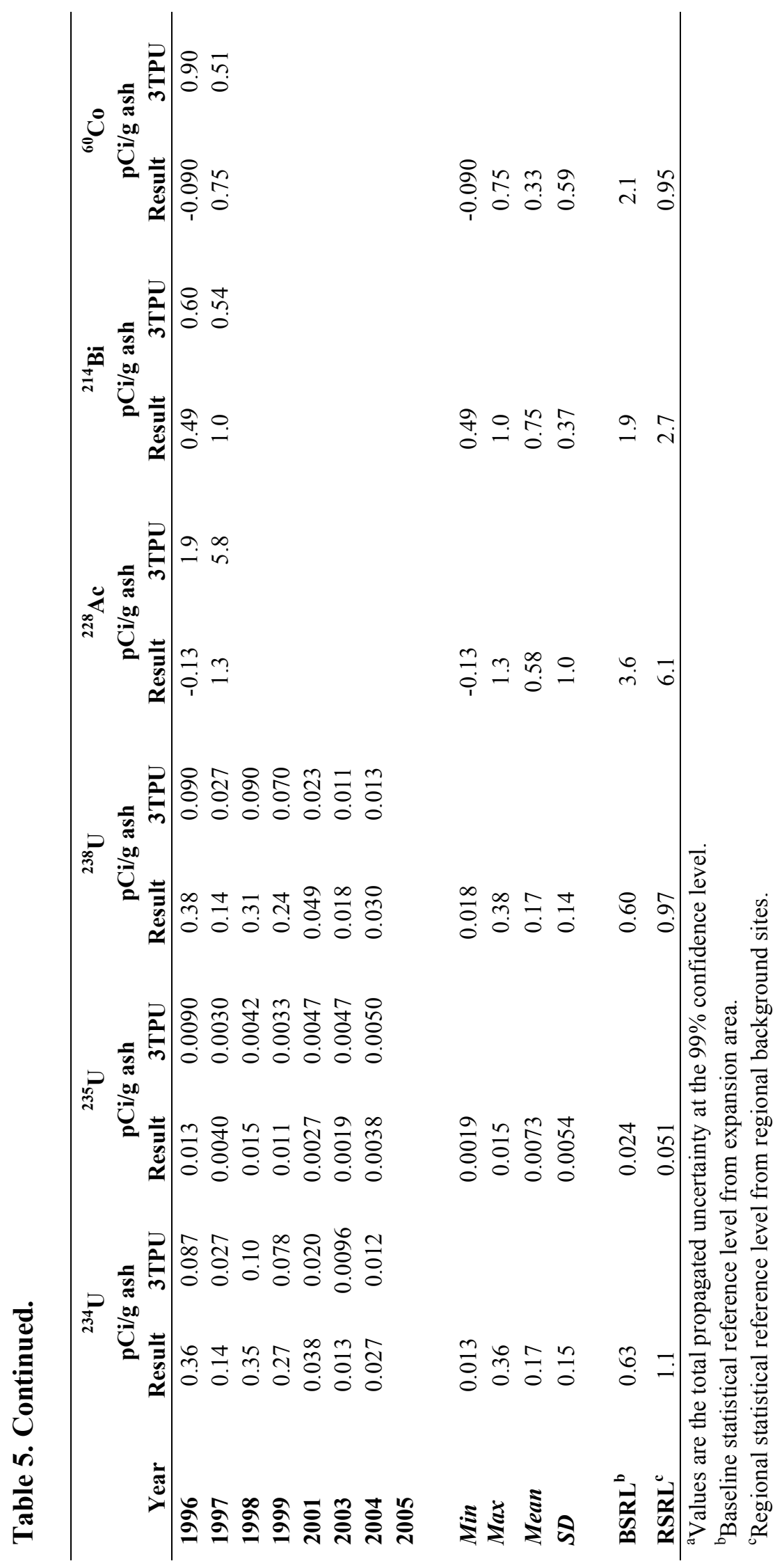




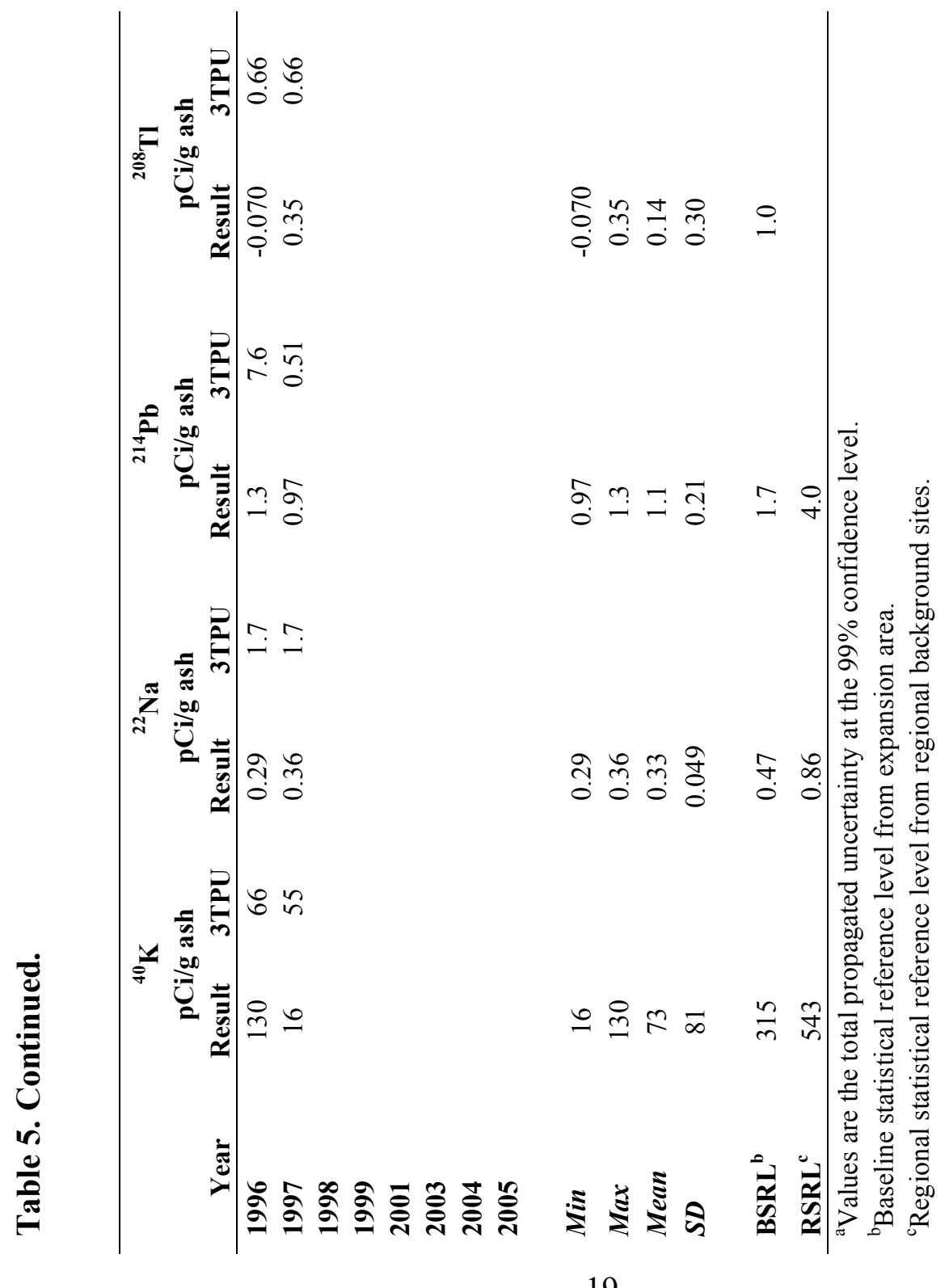




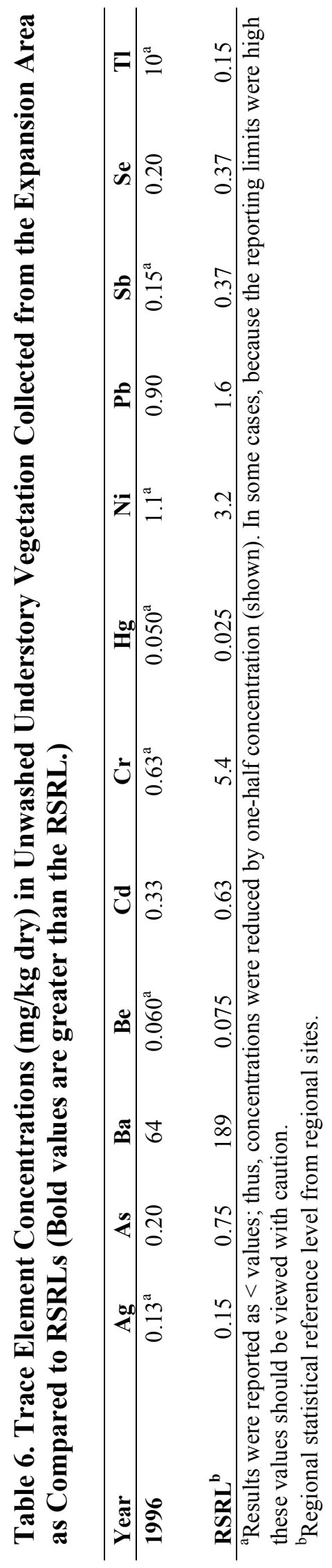




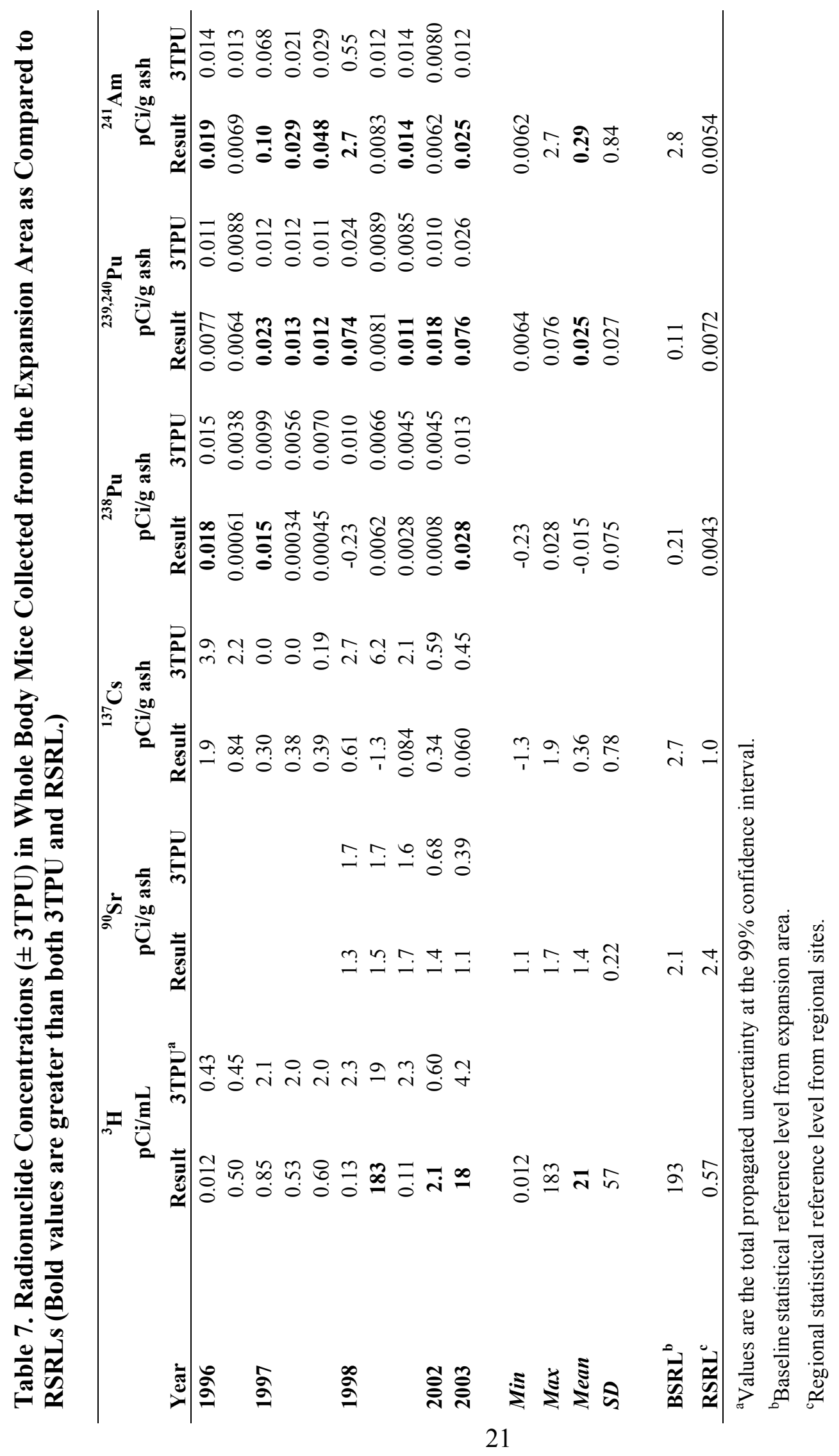




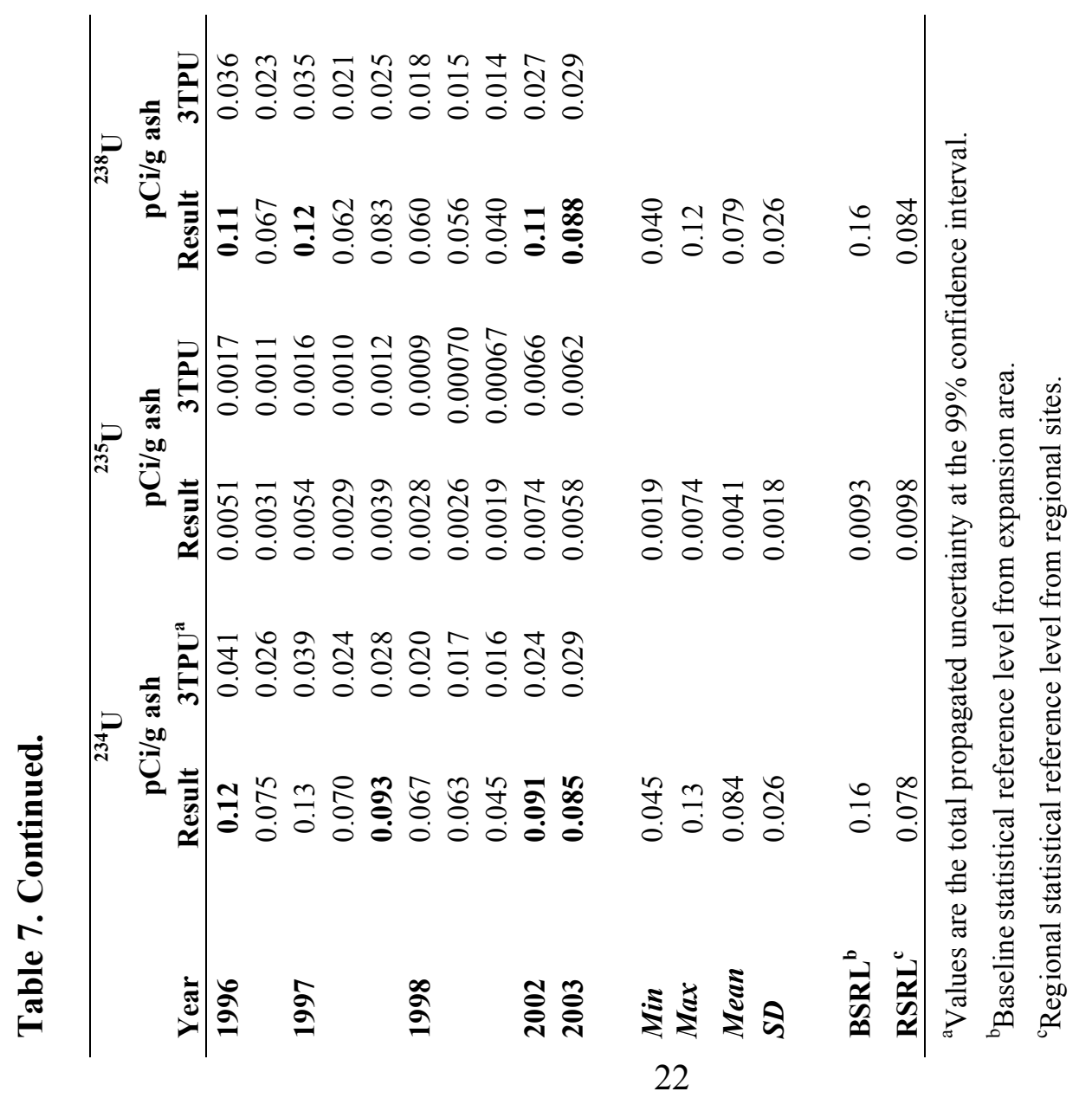


amounts of naturally occurring uranium in soil are generally higher in the Los Alamos area than in the surrounding areas (Fresquez et al., 1996). As for the other radionuclides detected in mice samples at the expansion area, it appears that these mice, because of their small home range, are probably picking up these radionuclides somewhere within the active pits on the northwestern side of Area G. The concentrations of these radionuclides in mice collected at the expansion area, however, are far below biota screening levels ( $10 \%$ of the biota dose standard of $0.1 \mathrm{rad} / \mathrm{d})$ and the mice are not at risk for receiving a potential unacceptable radiological dose (Soholt et al., 2003; Fresquez et al., 2005b).

Rock squirrels contained much lower concentrations of radionuclides than the field mice and, except for a few samples that contained ${ }^{3} \mathrm{H}$ and ${ }^{90} \mathrm{Sr}$ above RSRLs, the BSRLs were very similar to the RSRLs (Table 8). These data on rock squirrels are similar to those reported within the active management area in that not much radioactivity was picked up by the rock squirrels as compared to field mice (Fresquez et al., 2005b). Apparently, rock squirrels have different habitat characteristics (living area, foraging habits, etc.) than field mice that are not rendering themselves more susceptible to contamination from Area $\mathrm{G}$ as compared to the field mice. Past studies have shown that field mice contain higher amounts of radionuclides in the pelts than in the carcass (Biggs et al., 1995; Bennett et al., 1996) and are recognized as a mode of radionuclide uptake and transport at other waste disposal sites (Arthur et al., 1987). 


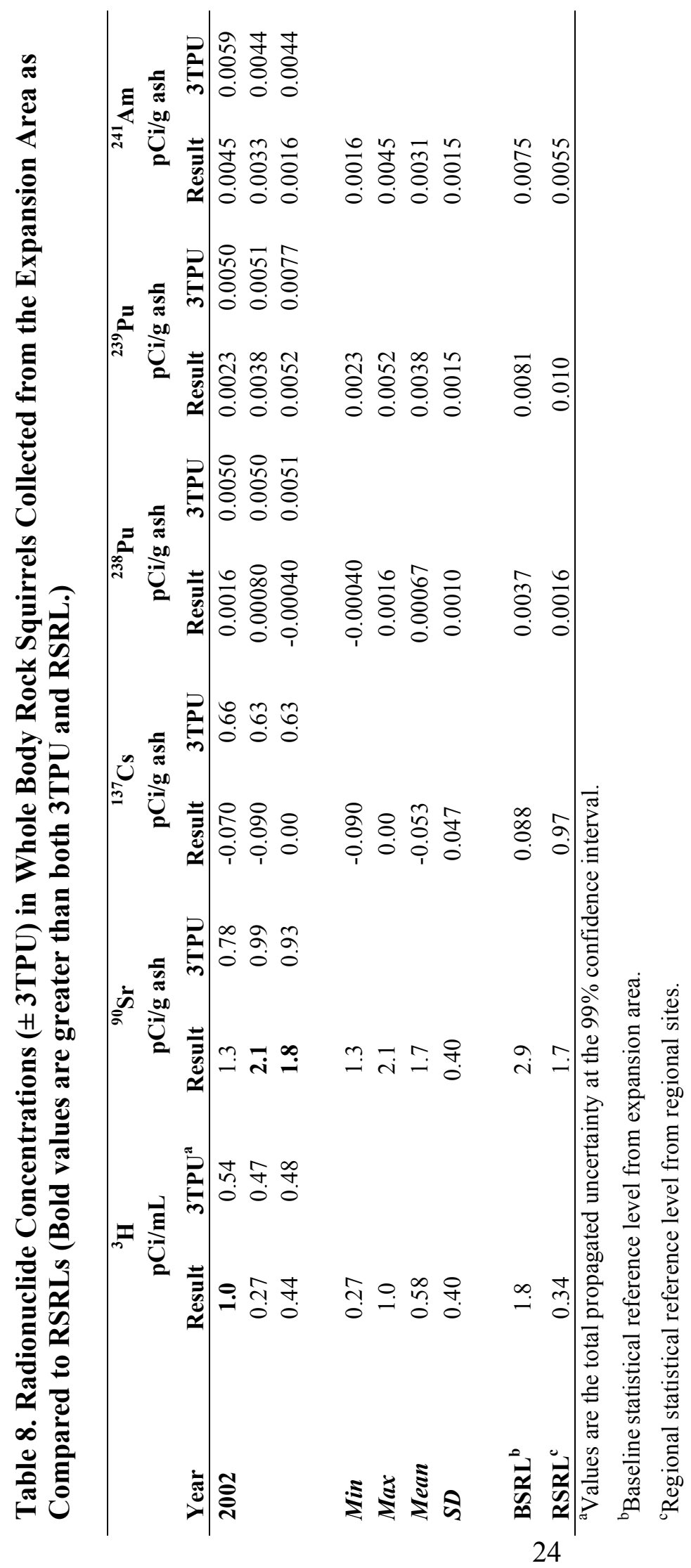


Table 8. Continued.

\begin{tabular}{lcccccc}
\hline & \multicolumn{2}{c}{${ }^{234} \mathbf{U}$} & \multicolumn{2}{c}{${ }^{235} \mathbf{U}$} & \multicolumn{2}{c}{${ }^{238} \mathbf{U}$} \\
Year & Result & 3TPU & \multicolumn{2}{c}{ pCi/g ash } & \multicolumn{2}{c}{ pCi/g ash } \\
\hline $\mathbf{2 0 0 2}$ & 0.063 & 0.020 & 0.0081 & 0.0068 & 0.057 & 0.020 \\
& 0.029 & 0.013 & 0.0038 & 0.0047 & 0.034 & 0.014 \\
& 0.060 & 0.020 & 0.0028 & 0.0050 & 0.065 & 0.021 \\
& & & & & & \\
Min & 0.029 & & 0.0028 & & 0.034 & \\
Max & 0.063 & & 0.0081 & & 0.065 & \\
Mean & 0.051 & & 0.0049 & & 0.052 & \\
SD & 0.019 & & 0.0028 & & 0.016 & \\
& & & & & & \\
BSRL $^{\mathbf{b}}$ & 0.11 & & 0.013 & & 0.10 & \\
RSRL $^{\mathbf{c}}$ & 0.18 & & 0.013 & & 0.20 & \\
\hline
\end{tabular}

${ }^{a}$ Values are the total propagated uncertainty at the $99 \%$ confidence interval.

${ }^{\mathrm{b}}$ Baseline statistical reference level from expansion area.

${ }^{\mathrm{c}}$ Regional statistical reference level from regional sites.

\section{Conclusions}

Most of the radionuclides and nonradionuclides in soil, vegetation, and small mammals from the expansion area were similar to regional background concentrations and can be used as a starting point for future environmental comparisons. Some radionuclides in mice samples occurred in higher concentrations than background and are probably a result of the ability of these animals to travel into contaminated media within the active management area.

\section{References}

Arthur, W.J., O.D. Markham, C.R. Groves, and B.L. Keller, "Radionuclide Export by Deer Mice at a Solid Radioactive Waste Disposal Area in Southeastern Idaho," Health Physics, 52(1):45-53 (1987).

Bennett, K.D., J.R. Biggs, and P.R. Fresquez, "Radionuclide Contaminant Analysis of Small Mammals at Area G, TA-54, 1995," Los Alamos National Laboratory report LA13242-MS (1996). 
Bennett, K., J. Biggs, and P.R. Fresquez, "Radionuclide Contaminant Analysis of Small Mammals at Area G, TA-54, 1997 (with Cumulative Summary for 1994-1997)," Los Alamos National Laboratory report LA-13517-MS (1998).

Bennett, K.D., R.J. Robinson, and P.R. Fresquez, "Radionuclide Contaminant Analysis of Small Mammals at Area G, Technical Area 54, 1998 (with Cumulative Summary for 1994-1998)," Los Alamos National Laboratory report LA-13874-MS (2002).

Biggs, J.R., K.D. Bennett, and P.R. Fresquez, "Radionuclide Contaminant Analysis of Small Mammals at Area G, TA-54, 1994," Los Alamos National Laboratory report LA13105-MS (1995).

Biggs, J.R., K.D. Bennett, and P.R. Fresquez, "Radionuclide Contaminant Analysis of Small Mammals at Area G, Technical Area 54, 1996 (with Cumulative Summary for 1994-1996)," Los Alamos National Laboratory report LA-13345-MS (1997).

Childs, M., and R. Conrad, "Area G Perimeter Surface Soil Sampling," Los Alamos National Laboratory report LA-13646-PR (1999).

Conrad, R., M. Childs, C. Rivera-Dirks, and F. Coriz, "Area G Perimeter Surface-Soil and Single-Stage Water Sampling," Los Alamos National Laboratory report LA-12986 (1995).

Fresquez, P.R., "Radionuclides, Heavy Metals, and Polychlorinated Biphenyls in Soils Collected Around the Perimeter of Low-Level Radioactive Waste Disposal Area G during 2006," Los Alamos National Laboratory report LA-14323-PR (2007).

Fresquez, P.R., and E. Lopez, "Radionuclide Concentrations in Soils and Vegetation at Low-Level Radioactive Waste Disposal Area G during the 2004 Growing Season," Los Alamos National Laboratory report LA-14181-PR (2004).

Fresquez, P.R., M.A. Mullen, J.K. Ferenbaugh, and R. Perona, "Radionuclides and Radioactivity in Soils Within and Around Los Alamos National Laboratory, 1974 through 1994: Concentrations, Trends, and Dose Comparisons," Los Alamos National Laboratory report LA-13149-MS (1996).

Fresquez, P.R., E.L. Vold, and L. Naranjo, Jr., "Radionuclide Concentrations in Soils and Vegetation at Radioactive-Waste Disposal Area G during the 1996 Growing Season," Los Alamos National Laboratory report LA-13332-PR (1997).

Fresquez, P.R., R.J. Wechsler, and L. Naranjo, Jr., "Radionuclide Concentrations in Soils and Vegetation at Radioactive-Waste Disposal Area G during the 1997 Growing Season," Los Alamos National Laboratory report LA-13495-PR (1998).

Fresquez, P.R., M.H. Ebinger, R.J. Wechsler, and L. Naranjo, Jr., "Radionuclide Concentrations in Soils and Vegetation at Low-Level Radioactive-Waste Disposal Area 
G during the 1998 Growing Season (with a Cumulative Summary of ${ }^{3} \mathrm{H}$ and ${ }^{239} \mathrm{Pu}$ Over Time)," Los Alamos National Laboratory report LA-13647-PR (1999).

Fresquez, P.R., J.W. Nyhan, and E. Lopez, "Radionuclide Concentrations in Soils and Vegetation at Low-Level Radioactive Waste Disposal Area G during the 2003 Growing Season," Los Alamos National Laboratory report LA-14108-PR (2004).

Fresquez, P.R., M.W. McNaughton, and M.J. Winch, "Radionuclide Concentrations in Soils and Unwashed Vegetation at Low-Level Radioactive Waste Disposal Area G during 2005," Los Alamos National Laboratory report LA-14251-PR (2005a).

Fresquez, P.R., L. Soholt, and E. Lopez, "Radionuclide Contaminant Analysis of Small Mammals at Area G, Technical Area 54, 2001 Through 2003 (with a Cumulative Summary for 1994 through 2003)," Los Alamos National Laboratory report LA-14193MS (2005b).

Fresquez, P.R., L.M. Vasquez-Tator, and E.A. Lopez, "Tritium Concentrations in Vegetation as a Function of Distance from a Low-Level Radioactive Waste Site at Los Alamos National Laboratory," Los Alamos National Laboratory report LA-14091-MS (2003).

Hansen, W.R., D.L. Mayfield, and L.J. Walker, "Interim Environmental Surveillance Plan for LASL Radioactive Waste Areas," Los Alamos Scientific Laboratory report LAUR-80-3110 (1980).

LANL (Los Alamos National Laboratory), "Closure/Post-Closure Plan for the Technical Area 54 Area G Landfill (Pit 29 and Shaft 124)," Los Alamos National Laboratory report LA-UR-06-1984 (2006).

Lopez, E.A., "MDA G and L Environmental Monitoring Plan for FY 2002," Los Alamos National Laboratory report LA-UR-02-6128 (2002).

Nyhan, J.W., P.R. Fresquez, W.R. Velasquez, and E.A. Lopez, "Radionuclide Concentrations in Soils and Vegetation at Low-Level Radioactive-Waste Disposal Area G during the 1999 Growing Season," Los Alamos National Laboratory report LA-13771PR (2000).

Nyhan, J.W., P.R. Fresquez, W.R. Velasquez, and E.A. Lopez, "Radionuclide Concentrations in Soils and Vegetation at Low-Level Radioactive-Waste Disposal Area G during the 2000 Growing Season," Los Alamos National Laboratory report LA-13864PR (2001).

Nyhan, J., P.R. Fresquez, R. Velasquez, and E. Lopez, "Radionuclide Concentrations in Soils and Vegetation at Low-Level Radioactive Waste Disposal Area G during the 2001 Growing Season,” Los Alamos National Laboratory report LA-13942-PR (2002). 
Nyhan, J., P.R. Fresquez, R. Velasquez, and E. Lopez, "Radionuclide Concentrations in Soils and Vegetation at Low-Level Radioactive Waste Disposal Area G during the 2002 Growing Season (With a Summary of Radionuclide Concentrations in Soils and Vegetation Since 1980)," Los Alamos National Laboratory report LA-14095-PR (2004).

Purtymun, W.D., M.A. Rogers, and M.L. Wheeler, "Radiochemical Analyses of Samples from Beneath a Solid Radioactive Waste Disposal Pit at Los Alamos, New Mexico," Los Alamos Scientific Laboratory report LA-8422-MS (1980).

Soholt, L.F., "Environmental Surveillance of Low-Level Radioactive-WasteManagement Areas at Los Alamos during 1987," Los Alamos National Laboratory report LA-UR-90-3283 (1990).

Soholt, L., G. Gonzales, P. Fresquez, K. Bennett, and E. Lopez, "Estimating Radiological Doses to Predators Foraging in a Low-Level Radioactive Waste Management Area," Los Alamos National Laboratory report LA-13999 (2003).

U.S. DOE (U.S. Department of Energy), "Final Environmental Impact Statement: Los Alamos Scientific Laboratory Site, Los Alamos, New Mexico," U.S. Department of Energy report DOE/EIS-0018 (1979). 


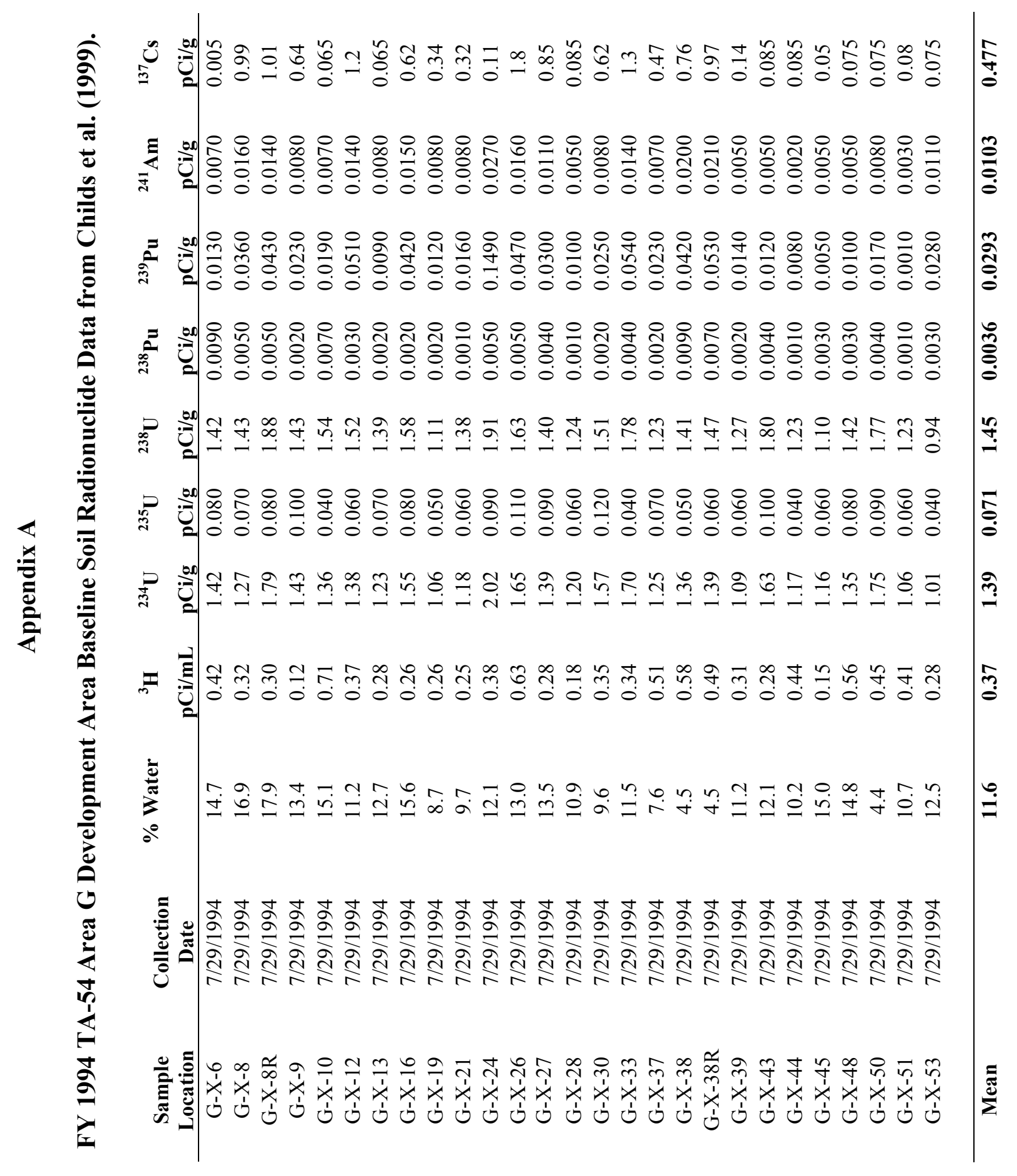


FY 1995 TA-54 Area G Development Area Baseline Soil Radionuclide Data from Childs et al. (1999).

\begin{tabular}{|c|c|c|c|c|c|c|c|c|}
\hline $\begin{array}{c}\text { Sample } \\
\text { Location }\end{array}$ & $\begin{array}{c}\text { Collection } \\
\text { Date }\end{array}$ & $\%$ Water & $\begin{array}{c}{ }^{3} \mathbf{H} \\
\mathrm{pCi} / \mathbf{m L}\end{array}$ & $\begin{array}{l}{ }^{234} \mathrm{U} \\
\mathrm{pCi} / \mathrm{g}\end{array}$ & $\begin{array}{l}{ }^{235} \mathrm{U} \\
\mathrm{pCi} / \mathrm{g}\end{array}$ & $\begin{array}{l}{ }^{238} \mathrm{U} \\
\mathrm{pCi} / \mathrm{g}\end{array}$ & $\begin{array}{r}{ }^{238} \mathrm{Pu} \\
\mathrm{pCi} / \mathrm{g}\end{array}$ & $\begin{array}{l}{ }^{239} \mathrm{Pu} \\
\mathrm{pCi} / \mathrm{g}\end{array}$ \\
\hline G-X-1 & $6 / 1 / 1995$ & 8.0 & -0.10 & 0.94 & 0.040 & 0.84 & 0.0040 & 0.0110 \\
\hline $\mathrm{G}-\mathrm{X}-2$ & 6/1/1995 & 11.5 & 0.00 & 0.96 & 0.040 & 0.86 & 0.0030 & 0.0080 \\
\hline $\mathrm{G}-\mathrm{X}-3$ & $6 / 1 / 1995$ & 7.5 & 0.00 & 1.28 & 0.053 & 1.14 & 0.0050 & 0.0160 \\
\hline G-X-4 & 6/1/1995 & 5.7 & 0.10 & 0.81 & 0.034 & 0.73 & 0.0010 & 0.0010 \\
\hline G-X-5 & 6/1/1995 & 5.2 & -0.30 & 0.81 & 0.034 & 0.73 & 0.0370 & 0.0520 \\
\hline G-X-11 & $6 / 1 / 1995$ & 12.4 & -0.20 & 0.99 & 0.042 & 0.89 & 0.0840 & 0.0450 \\
\hline G-X-14 & $6 / 1 / 1995$ & 14.5 & -0.40 & 0.95 & 0.040 & 0.85 & 0.0640 & 0.0400 \\
\hline G-X-15 & 6/1/1995 & 13.7 & 0.00 & 0.99 & 0.042 & 0.89 & 0.0060 & 0.0120 \\
\hline G-X-17 & $6 / 1 / 1995$ & 16.4 & -0.10 & 1.29 & 0.054 & 1.15 & 0.0030 & 0.0520 \\
\hline G-X-18 & $6 / 1 / 1995$ & 23.6 & -0.40 & 1.03 & 0.043 & 0.92 & 0.0020 & 0.0310 \\
\hline G-X-20 & $6 / 1 / 1995$ & 15.0 & 0.10 & 1.05 & 0.044 & 0.94 & 0.0040 & 0.0220 \\
\hline G-X-20R & $6 / 1 / 1995$ & 17.3 & -0.10 & 1.01 & 0.042 & 0.90 & 0.0680 & 0.0880 \\
\hline G-X-22 & 6/1/1995 & 14.0 & -0.20 & 0.99 & 0.042 & 0.89 & 0.0200 & 0.0050 \\
\hline G-X-23 & 6/1/1995 & 9.3 & -0.20 & 1.31 & 0.055 & 1.17 & 0.0400 & 0.0300 \\
\hline G-X-25 & 6/1/1995 & 7.1 & -0.30 & 1.20 & 0.050 & 1.07 & 0.0080 & 0.0150 \\
\hline G-X-29 & 6/1/1995 & 11.2 & -0.30 & 1.01 & 0.042 & 0.90 & 0.0070 & 0.0470 \\
\hline G-X-31 & $6 / 1 / 1995$ & 7.0 & -0.20 & 0.91 & 0.038 & 0.81 & 0.0040 & 0.0160 \\
\hline G-X-32 & 6/1/1995 & 13.4 & -0.10 & 1.04 & 0.043 & 0.93 & 0.0020 & 0.0040 \\
\hline G-X-34 & $6 / 1 / 1995$ & 18.2 & -0.20 & 1.03 & 0.043 & 0.92 & 0.0500 & 0.0400 \\
\hline G-X-35 & $6 / 1 / 1995$ & 8.9 & 0.00 & 1.41 & 0.059 & 1.26 & 0.0090 & 0.0230 \\
\hline G-X-36 & $6 / 1 / 1995$ & 16.7 & -0.20 & 1.22 & 0.051 & 1.09 & 0.0020 & 0.0080 \\
\hline G-X-40 & $6 / 1 / 1995$ & 17.8 & -0.10 & 1.19 & 0.050 & 1.06 & 0.0470 & 0.0460 \\
\hline G-X-41 & $6 / 1 / 1995$ & 22.3 & -0.30 & 1.07 & 0.045 & 0.96 & 0.0030 & 0.0100 \\
\hline G-X-42 & 6/1/1995 & 13.3 & 0.30 & 0.90 & 0.038 & 0.81 & 0.0030 & 0.0070 \\
\hline G-X-46 & $6 / 1 / 1995$ & 10.7 & -0.20 & 0.87 & 0.037 & 0.78 & 0.0020 & 0.0050 \\
\hline G-X-47 & 6/1/1995 & 16.4 & -0.10 & 0.99 & 0.042 & 0.89 & 0.0080 & 0.0110 \\
\hline G-X-49 & $6 / 1 / 1995$ & 15.2 & 0.00 & 1.08 & 0.045 & 0.97 & 0.0620 & 0.0260 \\
\hline G-X-49R & $6 / 1 / 1995$ & 15.4 & -0.30 & 0.95 & 0.040 & 0.85 & 0.0410 & 0.0070 \\
\hline G-X-54 & $6 / 1 / 1995$ & 6.2 & -0.20 & 0.90 & 0.037 & 0.80 & 0.0330 & 0.0100 \\
\hline G-X-55 & 6/1/1995 & 5.7 & -0.10 & 1.35 & 0.057 & 1.21 & 0.0040 & 0.0270 \\
\hline
\end{tabular}




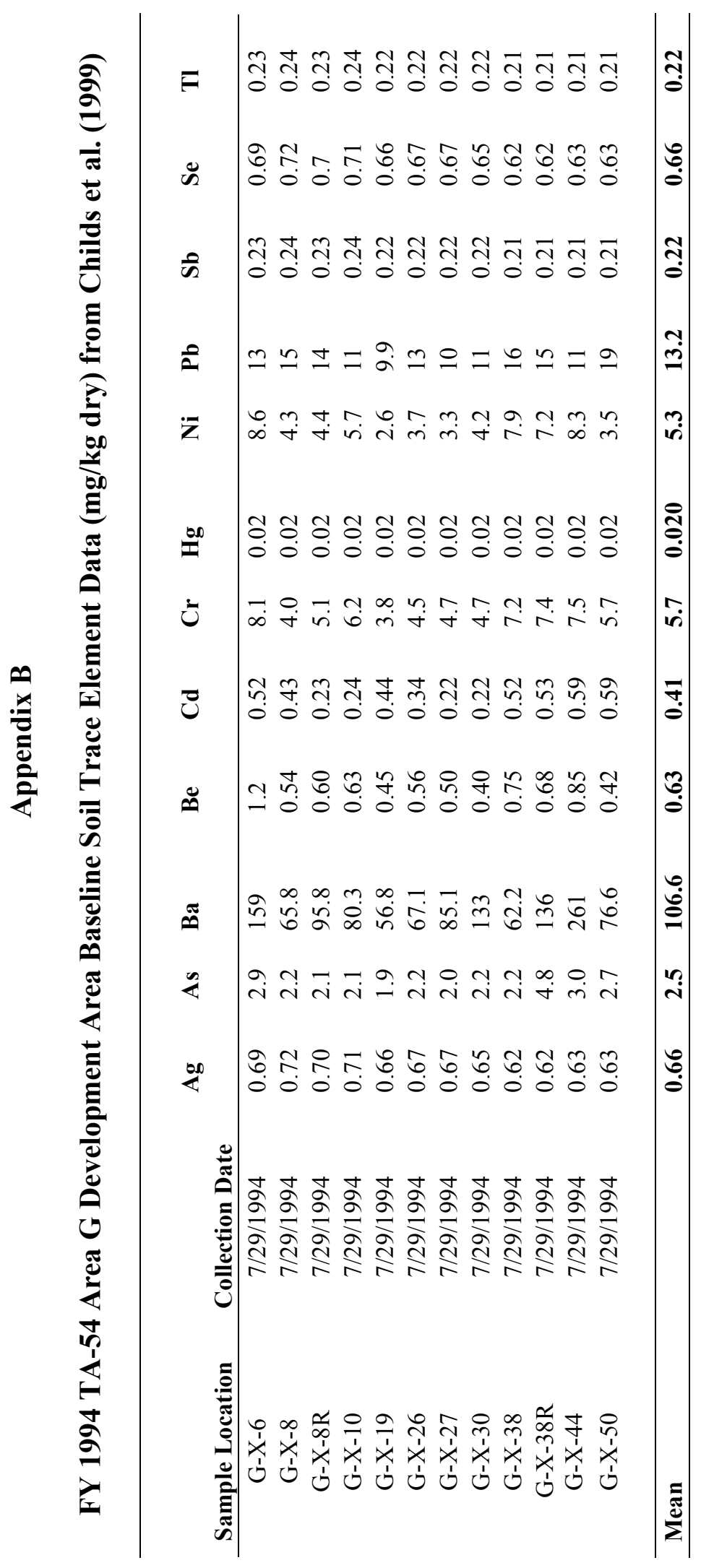




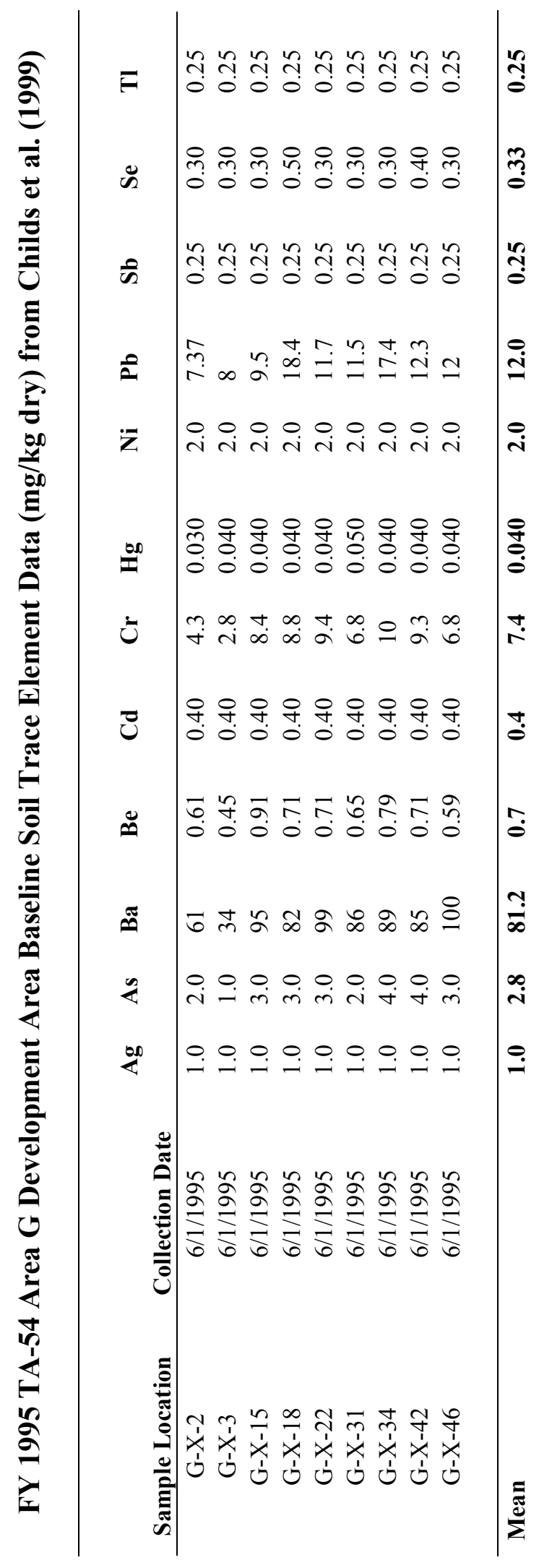




\section{Appendix C \\ Mice Whole Body Radionuclide Concentration Calculations}

To estimate the whole body calculation of each radionuclide in mice for the years 1996 through 1998, the following distribution was used for the pelt and carcass:

$7 \%$ pelt and $93 \%$ carcass by weight (determined from raw data, P.R. Fresquez personnel communication, 7-16-06)

Using this distribution and the reported radionuclide concentration for the pelt and carcass from the analytical laboratory, the whole body doses were calculated in the following manner:

(pelt radionuclide concentration $) \times(0.07)=$ concentration by weight (pelt) (carcass radionuclide concentration $) \times(0.93)=$ concentration by weight $($ carcass $)$

Concentration by weight (pelt) + concentration by weight (carcass) $=$ whole body radionuclide concentration 

This report has been reproduced directly from the best available copy. It is available electronically on the Web (http://www.doe.gov/bridge).

Copies are available for sale to U.S. Department of Energy employees and contractors from:

Office of Scientific and Technical Information

P.O. Box 62

Oak Ridge, TN 37831

(865) 576-8401

Copies are available for sale to the public from: National Technical Information Service

U.S. Department of Commerce

5285 Port Royal Road

Springfield, VA 22161

(800) 553-6847 
- Los Alamos NATIONAL LABORATORY

EST.1943 